\title{
Analisis Penerapan Sistem Manajemen Kinerja di PT AAA
}

\author{
Amrina Rasyada* \\ Program Studi Wijawiyata Manajemen, Sekolah Tinggi Manajemen PPM \\ Jl. Menteng Raya No.9, Kb. Sirih, Kec. Menteng, Kota Jakarta Pusat, Jakarta, Indonesia \\ inainarasyada@gmail.com \\ Dwi Idawati \\ Program Studi Magister Manajemen, Sekolah Tinggi Manajemen PPM \\ Jl. Menteng Raya No.9, Kb. Sirih, Kec. Menteng, Kota Jakarta Pusat, Jakarta, Indonesia \\ dwiidawati@gmail.com
}

Diterima: 09-02-2021

Disetujui: 16-06-2021

Dipublikasi: 30-06-2021

\begin{abstract}
ABSTRAK
PT AAA adalah perusahaan logistik dengan strategi bisnis menjadi perusahaan 4PL di Indonesia. Untuk mencapai strategi tersebut, perusahaan perlu meningkatkan kinerja bisnis dan sumber daya manusianya. Oleh karena itu, diperlukan sistem manajemen kinerja untuk menyelaraskan strategi bisnis dan kinerja individu karyawan, agar perusahaan dapat mencapai keunggulan kompetitif dan unggul pada kompetisi industri logistik. Penelitian ini dilakukan untuk menganalisis penerapan sistem manajemen kinerja menggunakan teori dari Aguinis (2014). Penelitian ini menggunakan pendekan kualitatif dan kuantitatif deskripstif dengan metode pengumpulan data: interview, Focus Group Discussion (FGD), survei (Weiss \& Hartle, 1997) dan studi dokumen. Hasil dari penelitian ini adalah pada tahap perencanaan diketahui strategi bisnis belum selaras dengan tujuan kinerja individu dan belum ditemukan adanya perjanjian kinerja. Pada tahap pelaksanaan, diketahui bahwa perusahaan belum memiliki jadwal pertemuan formal yang terstruktur Pada tahap penilaian, diketahui baahwa karyawan tidak ikut serta dalam roses penilaian dan pada tahap tindak lanjut kinera diketahui bahwa hasil dari manajemen kinerja tidak digunakan secara efektif.
\end{abstract}

Kata Kunci:

Sistem Manajemen Kinerja; Manajemen Sumber Daya Manusia; Perusahaan Logistik

\begin{abstract}
PT AAA is a logistics company with a strategic goal to become 4th Party Logistics in Indonesia. It needs to improve its business and human resource performances. Thus performance measurement system becomes a must for aligning business strategy with the individual performance so the company will achieve a competitive advantage and excels in the logistics industry competition. This study was designed to identify the management practice in the company by using performance management theory according to Aguinis (2014). This research uses qualitative and descriptive quantitative approaches with data collection methods: interviews, focus group discussions, surveys (Weiss \& Hartle, 1997), and document studies. The results of this research are in the planning phase, performance objectives are not cascaded from business strategy as well there is no performance plan meeting either. In the execution phase, it was found that the company doesn't conduct a scheduled formal performance meeting. In the appraisal phase, the employees are not involved in the appraisal process, and in the review phase, the performance results have not utilized effectively.
\end{abstract}

Keywords:

Performance Management System; Human Resource Management; Logistic Company 


\section{PENDAHULUAN}

Industri logistik merupakan salah satu industri penting dalam mendukung perekonomian Indonesia. Menurut Asosiasi Logistik dan Forwarder Indonesia (Katadata, 2019), potensi pertumbuhan bisnis logistik di Indonesia diprediksi akan mencapai lebih dari 30\% pada tahun 2020 dengan nilai sebesar 4 triliun rupiah. Tidak hanya itu, menurut proyeksi yang dilakukan oleh Ken Research (2019), diketahui bahwa pasar logistik di Indonesia akan mencapai USD 74,9 M pada tahun 2023.

PT AAA adalah salah satu perusahaan yang bergerak dalam industri logistik. PT AAA memiliki visi untuk menjadi penyedia solusi logistik terpadu yang terpercaya, terluas dan terkemuka di Indonesia. Berdasarkan Rancangan Perusahaan Jangka Panjang (RJPP) PT AAA tahun 2020-2024, diketahui tujuan strategis perusahaan selama lima tahun kedepan adalah menjadi perusahaan $4^{\text {th }}$ Party Logistics (4PL) di Indonesia dengan proyeksi pendapatan keuangan mencapai 2,8 triliun rupiah pada tahun 2024. Sesuai dengan pernyataan tersebut, tentu saja untuk mencapai strategi bisnis tersebut, perusahaan membutuhkan sumber daya manusia yang memiliki kinerja yang baik dan selaras dengan strategi perusahaan. Hal ini juga didukung oleh dengan penjelasan Armstrong (2006) yang menyatakan bahwa untuk meningkatkan kinerja perusahaan, perusahaan harus meningkatkan kinerja individu maupun tim.

Kinerja sumber daya dapat diukur dengan sistem manajemen kinerja. Sistem manajemen kinerja merupakan proses berkelanjutan yang terdiri dari identifikasi, pengukuran, dan pengembangan kinerja dalam organisasi dengan menghubungkan kinerja dan tujuan masing-masing individu dengan misi dan tujuan organisasi secara menyeluruh sehingga sistem manajemen kinerja merupakan salah satu hal yang perlu diterapkan dalam perusahaan (Aguinis, 2014). PT AAA sudah menerapkan sistem manajemen kinerja sejak tahun 2017, akan tetapi diketahui bahwa sistem manajemen kinerja di PT AAA masih baru dan perlu dilakukan penyempurnaan lebih lanjut. Menurut Aguinis (2004), penerapan manajemen kinerja yang tidak optimal akan menimbulkan beberapa konsekuensi seperti peningkatan turnover, penggunaan informasi yang salah, terbuangnya waktu dan biaya secara percuma, hubungan kerja yang buruk, penurunan motivasi kerja karyawan, ketidakpuasan akan pekerjaan, peningkatan resiko litigasi, pembagian beban kerja yang tidak rata, standar dan rating yang tidak adil, bias penilaian serta sistem rating yang tidak jelas, yang mana tentu saja hal tersebut dapat berdampak pada kinerja perusahaan.

Jika dilihat dari sisi kinerja keuangan perusahaan pada tahun 2019, diketahui PT AAA belum mencapai target pencapaian yang telah ditetapkan. Perusahaan hanya mencapai 79,70\% dari target yang telah ditetapkan. Dari sisi kepuasan pelanggan diketahui sebanyak 77,78\% pelanggan PT AAA saat ini masih bekerjasama dengan penyedia logistik lain Adapun dari tingkat kecelakaan, diketahui terjadi peningkatan angka kecelakaan dari 4 kecelakaan pada tahun 2018 menjadi 10 kecelakaan pada tahun 2019.

Keinginan PT AAA untuk terus maju dan meningkatkan kinerja perusahaan tentunya mengharuskan perusahaan untuk mengambil langkah strategis dalam pengelolaan manajemen kinerja 
karywan menjadi lebih baik lagi. Oleh karena itu, diperlukan analisis penerapan manajemen kinerja di PT. AAA.

\section{Manajemen Kinerja}

Aguinis (2014) menyatakan bahwa manajemen kinerja adalah suatu proses berkelanjutan dalam mengidentifikasi, mengukur dan mengembangkan kinerja organisasi, dimana kinerja dan tujuan setiap individu terhubung dengan tujuan dan misi organisasi. Beberapa tujuan manajemen kinerja adalah untuk tujuan strategis, tujuan administratif, tujuan informasi, tujuan pengembangan, tujuan pemeliharaan organisasi dan tujuan dokumentasi.

\section{Proses Manajemen Kinerja}

Menurut Aguinis (2014), proses manajemen kinerja adalah suatu proses berkelanjutan terkait dengan komponen- komponen yang saling terkait satu sama lain dalam memberikan dampak terhadap sistem manajemen kinerja keseluruhan. Komponen-komponen dari proses manajemen kinerja terdiri dari enam tahapan yaitu: prasyarat (prerequisities), perencanaan kinerja (performance planning), pelaksanaan kinerja (performance execution), penilaian kinerja (performance assessment), review kinerja (performance review) dan perbaikan kinerja \& kontrak (renewal \& recontracting performance. Gambar 1 menunjukkan proses manajemen kinerja menurut Aguinis (2014) sebagai berikut.

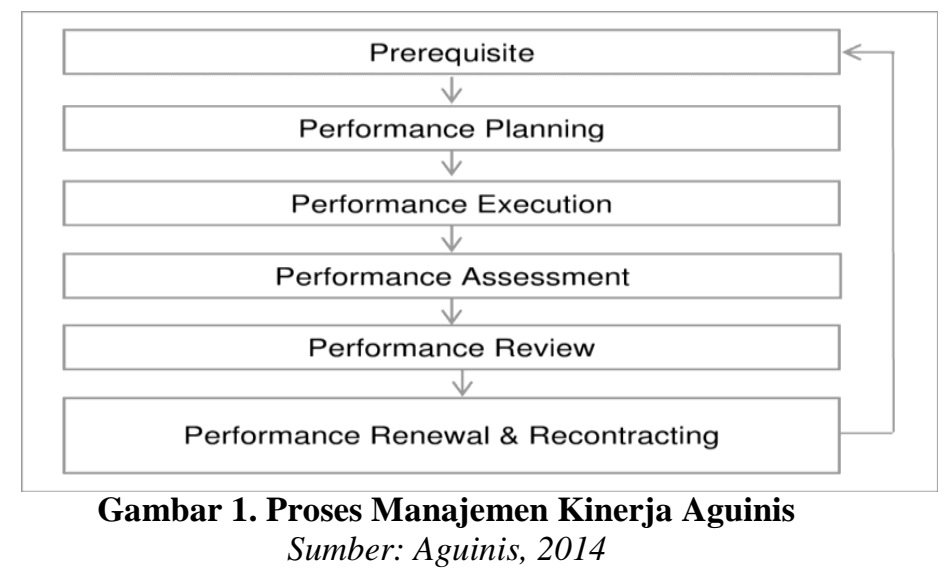

Adapun penjelasan setiap tahapan perencanaan manajemen kinerja adalah sebagai berikut:

\section{Prerequisities}

Tahapan prasyarat mengharuskan penyusun sistem manajemen kinerja untuk memahami dua hal penting yaitu visi-misi-tujuan strategis perusahaan dan pengetahuan tentang uraian pekerjaan yang dilakukan. Kedua hal ini perlu diketahui agar tercipta perencanaan strategis di perusahaan. Setelah perencanaan strategis dilakukan, maka uraian pekerjaan dapat disesuaikan dengan pekerjaan yang dapat membantu tujuan strategis perusahaan.

\section{Performance Planning}

Tahapan ini adalah tahap perencanaan manajemen kinerja. Saat melakukan perencanaan, pekerja dan supervisor harus bertemu untuk mendiskusikan uraian pekerjaan dan bagaimana mengerjakan pekerjaan yang disepakati bersama. Dalam tahap perencaaan, ada tiga indikator 
yang perlu diperhatikan yaitu hasil kerja (results), perilaku kerja (behavior), dan rencana pengembangan (development plan).

3. Performance Execution

Tahapan ini merupakan tahapan dilakukan pelaksanaan kinerja. Dalam tahapan ini, semua stakeholder harus berpartisipasi aktif dalam melakukan kinerja, memonitor pekerjaan masingmasing, dan selalu melakukan komunikasi dua arah.

4. Performance Assessment

Dalam tahap penilaian kinerja, pekerja dan manajer bertanggungjawab melakukan evaluasi terhadap perilaku yang diharapkan dan hasil yang harus dicapai. Dalam penilaian kinerja, karyawan dan atasan bertanggung jawab untuk mengevaluasi keseluruhan perilaku yang ditampilkan dan apakah hasil yang diharapkan tercapai. Tahap ini merupakan tahap yang dilakukan di akhir periode.

\section{Performance Review}

Setelah melakukan penilaian kinerja, maka tahapan selanjutnya adalah mereview kinerja yang telah dilakukan. Pertemuan ini sangat penting karena pertemuan ini menyediakan kesempatan formal dimana pekerja menerima umpan balik terhadap hasil pekerjaannya. Performance review dapat dilakukan secara bulanan, 6 bulan, atau akhir tahun.

\section{Performance Renewal \& Recontracting}

Tahap akhir dari proses manajemen kinerja adalah renewal dan recontracting. Tahapan ini merupakan tahapan dimana pekerja dan atasan memberikan informasi tambahan mengenai uraian pekerjaan dan Knowledge, Skill, Attitudes (KSAs) yang diperlukan berdasarkan hasil review, umpan balik, dan coaching yang telah dilakukan.

\section{METODE RISET}

Jenis penelitian yang digunakan dalam penelitian ini adalah mixed method yang menggabungkan dua pendekatan penelitian, yaitu kualitatif dan kuantitatif deskriptif. Jenis data yang digunakan dalam penelitian ini adalah primer dan data sekunder. Data primer dalam penelitian ini didapat melalui proses wawancara, Focus Group Discussion (FGD) dan survei dengan penyebaran kuesioner modifikasi dari Weiss \& Hartle (1997). Adapun data sekunder didapat dari studi dokumen dan studi literatur.

Populasi penelitian ini adalah karyawan PT AAA Kantor Pusat sebanyak 66 orang. Adapun untuk sampel penelitian, untuk wawancara akan digunakan teknik purposive sampling dengan narasumber Corporate Planning, VP Human Capital, VP Freight Forwarding dan Officer Human Capital. Peneliti juga melakukan FGD dengan divisi Contract Logistics Adapun sampel untuk metode survei dengan menggunakan kuesioner adalah minimal 80\% dari karyawan kantor pusat PT AAA yang 
terdiri dari Direktorat Bisnis I, Direktorat Bisnis II, Direktorat Umum dan Keuangan, divisi Corporate Secretary dan divisi QHSE dengan total berjumlah 53 orang.

\section{Kerangka Analisis}

Kerangka analisis yang digunakan pada penelitian ini adalah sebagai berikut,

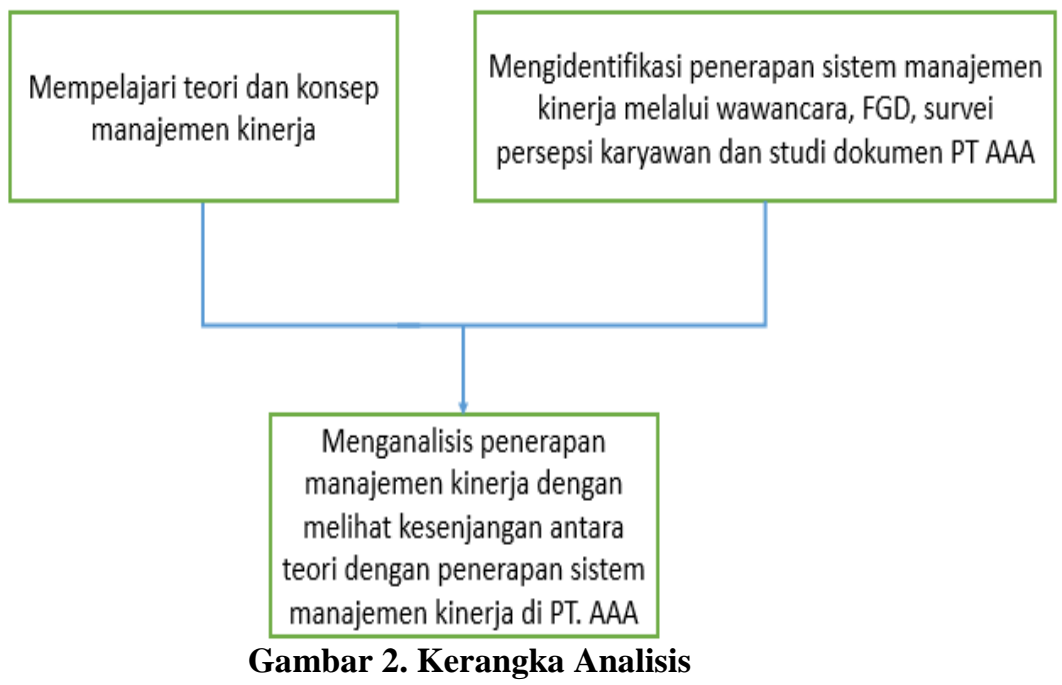

Analisis penerapan manajemen kinerja PT AAA dilakukan dengan cara mempelajari teori dan konsep manajemen kinerja dari Aguinis (2014) dan Weiss dan Hartle (1997). Selanjutnya, peneliti mengidentifikasi penerapan sistem manajemen kinerja yang ada di perusahaan melalui wawancara, FGD, survei persepsi karyawan dan studi dokumen di PT AAA. Kemudian, peneliti menganalisis penerapan manajemen kinerja dengan melihat kesenjangan antara teori dengan penerapan sistem manajemen kinerja di PT AAA.

\section{HASIL PENELITIAN DAN PEMBAHASAN}

Sesuai dengan kerangka analisis, setelah mempelajari teori manajemen kinerja, peneliti perlu mengidentifikasi penerapan sistem manajemen kinerja yang diterapkan di perusahaan saat ini. Berikut adalah hasil temuan penerapan manajemen kinerja.

\section{Hasil Wawancara}

Hasil wawancara secara lengkap dapat dilihat pada lampiran 1. Berikut adalah kesimpulan hasil wawancara:

a. Tahap Perencanaan

1) Perusahaan sudah menerapkan manajemen kinerja sejak tahun lalu, hanya saja sistem yang ada masih perlu diperbaiki.

2) Penilaian kinerja yang ada sudah diturunkan dari strategi bisnis yang ada di perusahaan namun cenderung di keuangan dan absensi. Sudah ada pengukuran untuk hasil dan proses namun kurang sistematis. 
3) Perencanaan kinerja yang ada masih bersifat satu arah dan belum melibatkan karyawan yang bersangkutan secara langsung.

4) Penyusunan kerja sudah menyesuaikan uraian tugas secara garis besar, namun memang belum selaras penuh dengan uraian tugas yang ada dan karyawan merasa penurunannya tidak sistematis.

b. Tahap Pelaksanaan

1) Karyawan dan atasan belum berpartisipasi secara aktif karena belum ada sistem pelaksanaan kinerja yang terstruktur dan terjadwal. Pelaksanaan kinerja bergantung pada atasan masing-masing mulai dari proses umpan balik, dokumentasi dan proses monitoring lainnya. Beberapa atasan melakukan supervisi langsung kepada bawahannya.

2) Beberapa divisi tidak memiliki meeting mingguan dan bulanan.

c. Tahap Penilaian

1) Penilaian kinerja dilakukan pada akhir tahun.

2) Penilaian kinerja dilakukan oleh atasan yang bersangkutan saja, tanpa melibatkan karyawan yang bersangkutan. Beberapa atasan masih bingung dalam memberikan penilaian kepada karyawannya karena belum ada standar pasti dalam melakukan penilaian kinerja.

3) Penilaian kinerja tidak dapat dibanding.

4) Perusahaan melakukan penilaian kinerja sesuai norma dan etika yang berlaku.

d. Tahap Tindak Lanjut

1) Hasil penilaian belum dikomunikasikan ke pihak terkait. Perusahaan belum mengagendakan pertemuan formal terkait manajemen kinerja.

2) Hasil penilaian kinerja tidak mempengaruhi kompensasi karyawan saat ini, namun kedepannya diharapkan hasil kinerja dapat mempengaruhi kompensasi.

3) Manajemen kinerja dapat menjadi alat kontrol kinerja dan pertimbangan strategis kedepannya

\section{Hasil FGD}

Hasil wawancara secara lengkap dapat dilihat pada lampiran 2. Kesimpulan temuan penerapan manajemen kinerja berdasarkan hasil FGD Contract Logistics adalah:

a. Tahap Perencanaan

Perencanaan manajemen kinerja adalah kewenangan SDM. Sejauh ini karyawan tidak dilibatkan secara langsung dalam proses perencanaan kinerja. Tidak ada pertemuan khusus antara atasan dan bawahan dalam membahas perencanaan kinerja

b. Tahap Pelaksanaan

Pelaksanaan kinerja yang ada di divisi kinerja dilakukan oleh atasan dan bawahan secara dua arah. Atasan melakukan pemantauan atas pekerjaan yang dilakukan. Atasan memberi 
umpan balik secara berkelanjutan. Karyawan melakukan tugasnya sesuai ruang lingkup yang telah diberikan oleh atasan. Karyawan dan atasan melakukan komunikasi dua arah terkait pekerjaan yang dilakukan.

c. Tahap Penilaian

1) Hanya atasan yang melakukan penilaian kinerja tanpa berkomunikasi dengan karyawan yang bersangkutan, dan hasilnya langsung diberikan ke pihak SDM. Penilaian kinerja saat ini hanya dilakukan oleh atasan saja dan tidak melibatkan karyawan yang bersangkutan. Beberapa Karyawan tidak mengetahui ada sistem penilaian kinerja di perusahaan.

2) Diharapkan kedepannya perusahaan dapat melakukan digitalisasi atas prosedur penilaian sehingga akan lebih memudahkan proses penilaian kinerja

d. Tindak Lanjut

1) Hasil penilaian kinerja yang ada akan digunakan untuk perpanjangan kontrak karyawan.

2) Hasil dari penilaian manajemen kinerja ini masih belum diintegrasikan secara konkrit sehingga belum terlihat tindak lanjut secara berkelanjutan.

3) Diharapkan manajemen kinerja kedepannya dapat terintegrasi dengan seluruh kegiatan SDM lainnya

\section{Hasil Survei Persepsi Karyawan}

Untuk mengetahui penerapan manajemen kinerja berdasarkan persepsi karyawan, peneliti membagikan kuesioner pada tanggal 28 Maret 2020 kepada seluruh karyawan kantor pusat PT AAA sebanyak 66 orang secara online. Dari penyebaran tersebut, 53 kuesioner kembali,13 kuesioner tidak kembali dan 2 pernyataan tidak valid karena tidak memenuhi batas minimal $r$ tabel yaitu 0,2706.

\section{a. Hasil Survei Pertanyaan Tertutup}

Skala nilai yang digunakan dalam pertanyaan tertutup adalah skala likert dengan rentang 1-4 untuk menghindari central tendency (Sangat tidak setuju, tidak setuju, setuju, sangat setuju). Berdasarkan tabel interpretasi Hague (1995) nilai rata-rata minimal yang diperlukan agar proses manajemen tersebut dikategorikan baik adalah minimal 3,2 dari total nilai 4.

Berdasarkan hasil survei karyawan, diketahui nilai rata-rata keseluruhan proses manajemen kinerja (perencanaan, pelaksanaan, penilaian \& tindak lanjut) berada di angka 2,983 sehingga diperlukan perbaikan pada penerapan sistem manajemen kinerja di PT AAA

Hasil Survei Manajemen Kinerja

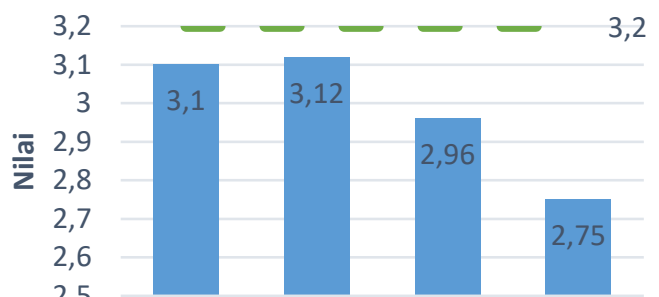


Gambar 3. Hasil Survei Manajemen Kinerja

Sumber: Hasil Pengolahan Kuesioner Penelitian PT. AAA, 2018

Berdasarkan gambar tersebut, dapat dilihat bahwa semua tahapan berada dibawah standar penerapan manajemen kinerja. Oleh karena itu, perusahaan perlu memperbaiki tahapan manajemen kinerja. Selanjutnya akan dijelaskan hasil dari masing-masing tahapan.

1) Perencanaan Kinerja

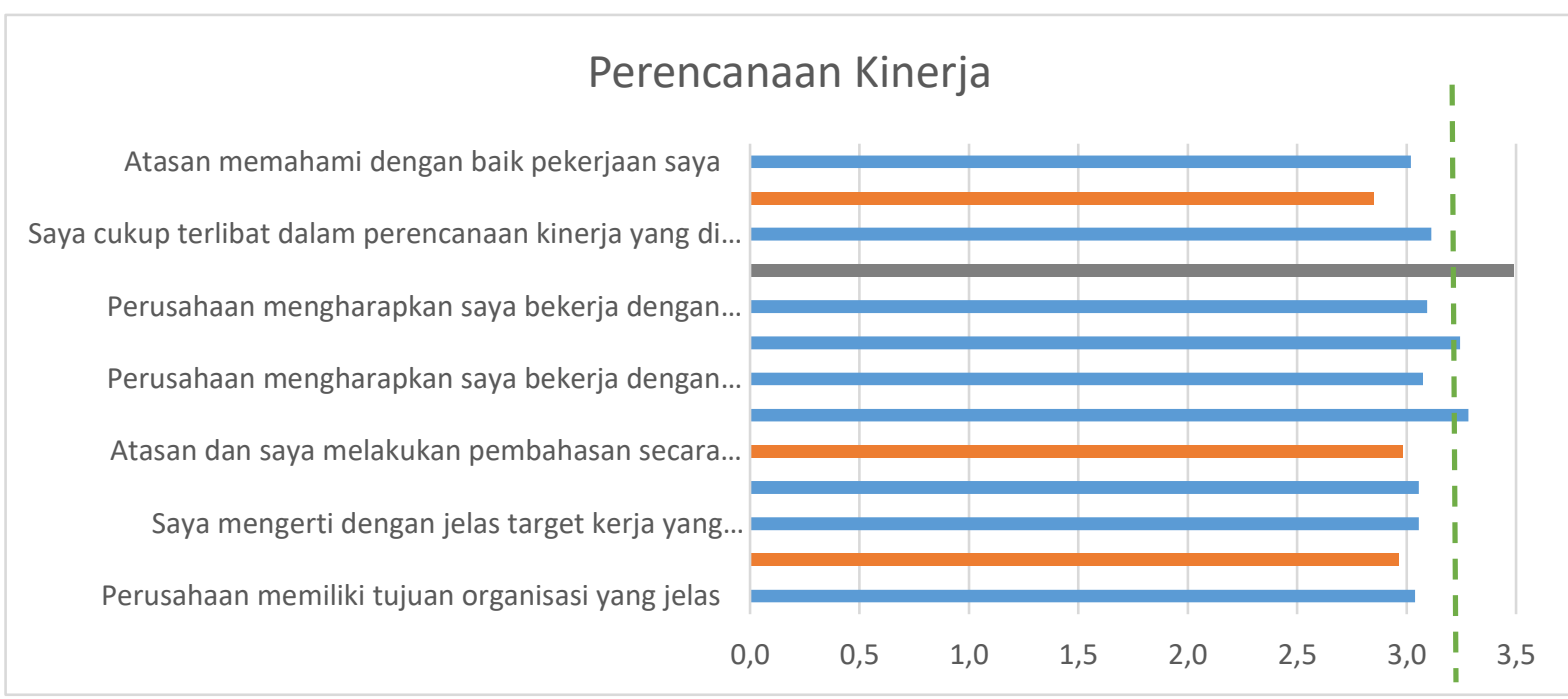

Gambar 4. Rekapitulasi Respon Kuesioner Perencanaan Kinerja Sumber: Hasil Pengolahan Kuesioner Penelitian PT. AAA, 2018

Berdasarkan gambar diatas, diketahui nilai rata-rata perencanaan kinerja adalah sebesar 3,1 dari nilai maksimal 4. Pernyatan yang paling banyak disetujui oleh karyawan adalah 'Perusahaan mengharapkan saya bekerja dengan tepat waktu' dengan nilai 3,49. Adapun pernyataan dengan nilai rendah adalah 'Atasan dan saya membuat perencanaan kinerja saya pada setiap awal tahun' yaitu dengan nilai 2,85 . Pernyataannya dengan nilai rendah lainnya adalah pernyataan 'Kinerja yang di harapkan dari saya sejalan dengan rencana organisasi' dengan nilai 2,96 dan 'Atasan dan saya melakukan pembahasan secara personal untuk membicarakan apa yang diharapkan dari kinerja saya'.

2) Pelaksanaan Kinerja 


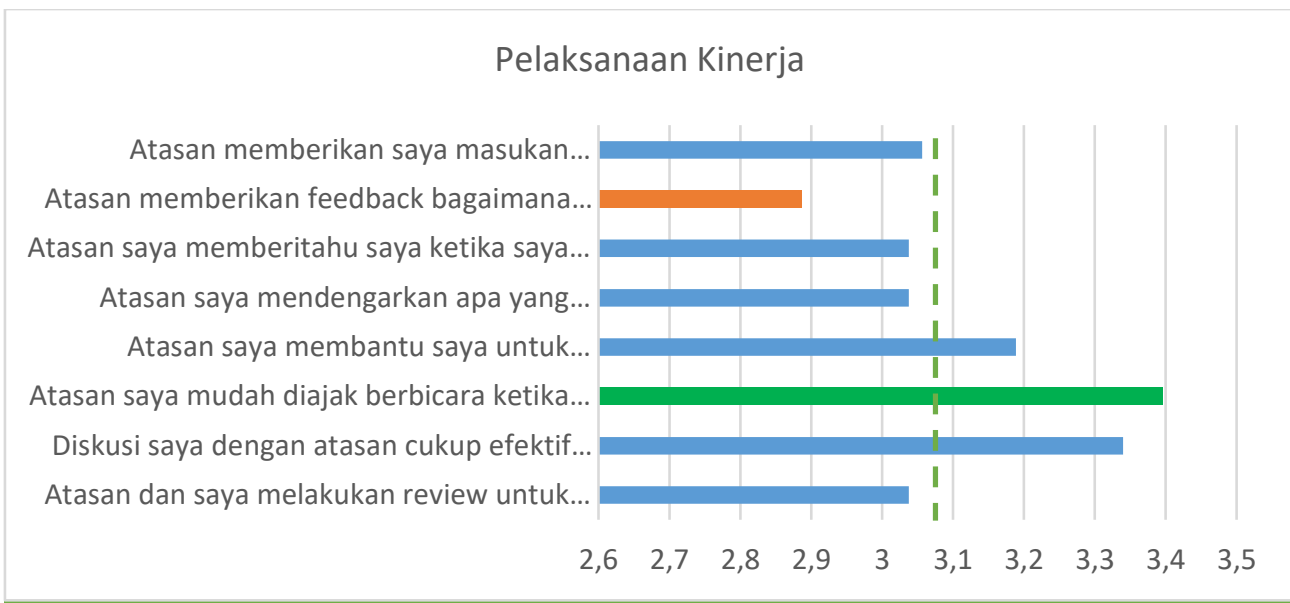

\section{Gambar 5. Rekapitulasi Respon Kuesioner Pelaksanaan Kinerja}

Sumber: Hasil Pengolahan Kuesioner Penelitian PT. AAA, 2018

Berdasarkan gambar diatas, diketahui nilai rata-rata pelaksanaan kinerja adalah sebesar 3,12 dari nilai maksimal 4. Pernyatan yang paling banyak disetujui oleh karyawan adalah 'Atasan saya mudah diajak berbicara ketika saya memiliki masalah dalam pekerjaan' dengan nilai 3,39. Adapun pernyataan dengan nilai 2,89 yaitu dengan nilai paling rendah adalah 'Atasan memberikan umpan balik bagaimana saya berupaya untuk mencapai hasil yang di harapkan dari saya'.

3) Penilaian Kinerja

\section{Penilaian Kinerja}

Hal-hal yang di gunakan untuk mengukur.. Saya memahami bahwa saya bisa...

Penilaian kinerja saya dilakukan dengan.. Saya merasa nyaman saat melakukan... Hasil kinerja saya akurat dengan hasil..

Saya tahu apa yang perlu saya lakukan. Saya tidak kaget terhadap hasil penilaian.. Perusahaan tidak mentolelir kinerja yang.. Atasan saya menilai kinerja saya secara adil

Saya mengerti dengan jelas bagaimana.. Perusahaan memiliki sistem penilaian.

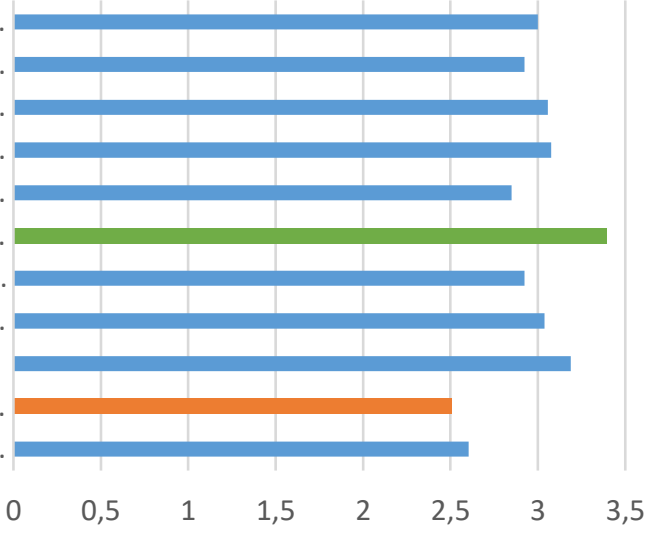

Gambar 6. Rekapitulasi Respon Kuesioner Penilaian Kinerja Sumber: Hasil Pengolahan Kuesioner Penelitian PT. AAA, 2018

Berdasarkan gambar diatas, diketahui nilai rata-rata penilaian kinerja adalah sebesar 2,96 dari nilai maksimal 4. Pernyataan yang paling banyak disetujui oleh karyawan adalah 'saya tahu apa yang perlu saya lakukan untuk mencapai apa yang diharapkan dari pekerjaan saya' dengan nilai 3,39. Adapun pernyataan dengan nilai 2,5 yaitu dengan nilai paling rendah adalah 'saya mengerti dengan jelas bagaimana sistem penilaian kinerja di perusahaan'. 
4) Tindak Lanjut Kinerja

\section{Tindak Lanjut Kinerja}

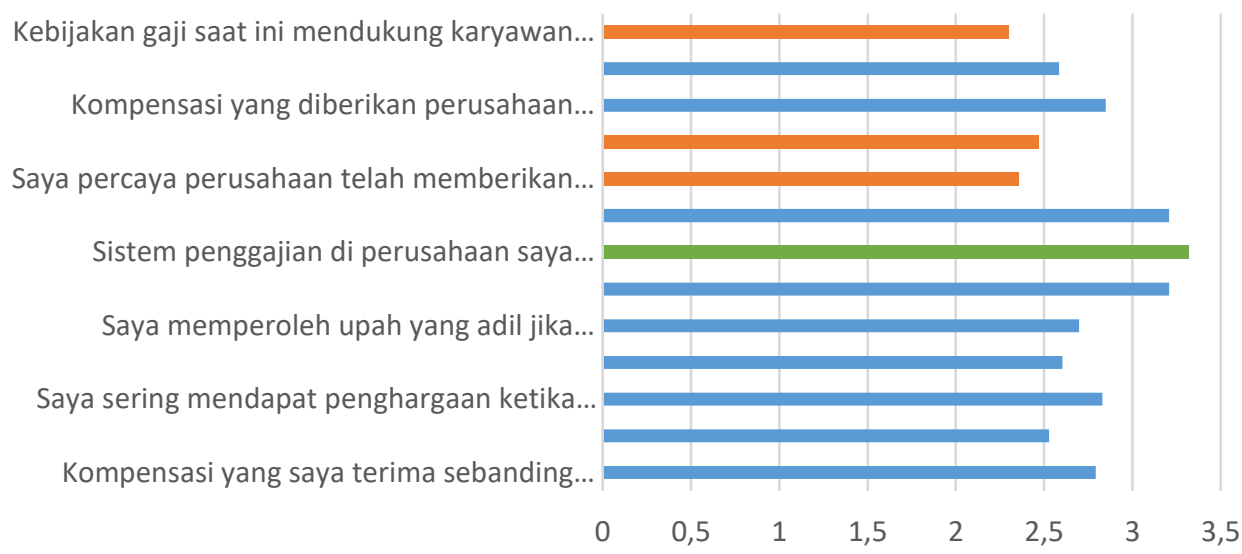

Gambar 7. Rekapitulasi Respon Kuesioner Tindak Lanjut Kinerja Sumber: Hasil Pengolahan Kuesioner Penelitian PT. AAA, 2018

Berdasarkan gambar diatas, diketahui nilai rata-rata tindak lanjut kinerja adalah sebesar 2,75 dari nilai maksimal 4. Pernyatan yang paling banyak disetujui adalah 'Sistem penggajian di perusahaan saya seharusnya didasarkan pada kinerja organisasi secara keseluruhan' dengan nilai 3,32. Pernyataan dengan nilai paling rendah adalah 'Kebijakan gaji saat ini mendukung karyawan untuk bekerja sebagai tim'. Adapun penyataan lain yang mendapat nilai rendah adalah 'Saya percaya perusahaan telah memberikan informasi akurat mengenai skema kompensasi' sebesar 2,36 dan 'Perusahaan menerangkan alasan dengan baik jika ada perubahaan kompensasi' dengan nilai 2,47.

\section{b. Hasil Survei Pertanyaan Terbuka}

Terdapat tiga pertanyaan terbuka yang peneliti ajukan kepada karyawan untuk mengetahui persepsi karyawan terhadap penerapan manajemen kinerja yang ada di perusahaan. Adapun pernyataan terbuka yang diajukan adalah:

1) Perlukah sistem manajemen kinerja yang bertujuan untuk meningkatkan kinerja karyawan? Mengapa?

2) Menurut Bapak/Ibu, hasil penilaian kinerja dapat dilakukan untuk apa saja?

3) Apa usulan Bapak/Ibu untuk perbaikan sistem penilaian kinerja di perusahaan?

Jawaban responden akan dikelompokkan berdasarkan tahapan penilaian kinerja menurut teori Wiess \& Hartle. Hasil rekapitulasi persepsi karyawan atas pertanyaan terbuka pertama dapat dilihat pada Tabel 1, 
Tabel 1. Rekapitulasi Hasil Pertanyaan Terbuka No. 1

Tahapan

Proses MK

Perencanaan

Tindak Lanjut

Pertanyaan:

Perlukah sistem manajemen kinerja yang bertujuan untuk meningkatkan kinerja karyawan? Mengapa?

Sebanyak 9\% responden merasa perusahaan perlu memiliki sistem manajemen kinerja untuk mencapai tujuan bersama antara perusahaan dan karyawan

Sebanyak $4 \%$ responden merasa perusahaan memerlukan sistem kinerja untuk menjadi bahan tolak ukur penilaian kinerja

Sebanyak 6\% responden merasa perusahaan perlu memiliki sistem manajemen kinerja karena perusahaan harus mengetahui kemampuan setiap karyawannya

Sebanyak $11 \%$ responden merasa perusahaan perlu sistem kinerja yang terarah dan transparan agar dapat memotivasi karyawan untuk mencapai tujuan perusahaan

Sebanyak 9\% responden merasa perusahaan memerlukan sistem baik agar menjadi stimulus bagi karyawan untuk mengingkatkan produktivitas karyawan

Sebanyak $13 \%$ responden merasa perusahaan memerlukan sistem manajemen kinerja agar karyawan dapat dinilai dengan adil

Sebanyak 38\% responden merasa perusahaan memerlukan sistem manajemen kinerja untuk menentukan kompensasi struktur upah, kenaikan gaji, promosi, kebutuhan pelatihan dan lain sebagainya.

Sebanyak 9\% responden merasa perusahaan memerlukan sistem manajemen kinerja agar hasil evaluasinya dapat menjadi dasar pengambilan keputusan dan kebijakan

Hasil rekapitulasi persepsi karyawan atas pertanyaan terbuka kedua dapat dilihat pada Tabel 2

Tabel 2. Rekapitulasi Hasil Pertanyaan Terbuka No. 2

\begin{tabular}{ll}
\hline \multicolumn{1}{c}{ Pertanyaan } & \multicolumn{1}{c}{ Jawaban Responden } \\
\hline Menurut & Promosi dan pola karir sebanyak 32\% \\
Bapak/Ibu, hasil & Kebutuhan pelatihan dan pengembangan sebanyak 28\% \\
penilaian kinerja & Analisa kebutuhan manpower sebanyak 4\% \\
dapat dilakukan & Penentuan mutasi-demosi sebanyak 9\% \\
untuk apa saja? & Sebagai bahan evaluasi dan penetapan kebijakan selanjutnya sebanyak 6\% \\
& Sebagai alat untuk memotivasi diri sendiri lebih baik lagi jika merasa tidak sesuai dengan \\
& harapan 4\% \\
& Sebagai penambah bonus tunjangan sebanyak 6\% \\
& Sebagai dokumentasi atas kinerja karyawan dimasa lalu sebanyak 4\% \\
& Sebagai alat untuk menganalisa kemampuan karyawan secara individual dan menyusun \\
& sasaran dimasa mendatang sebanyak 8\% \\
\hline
\end{tabular}

Hasil rekapitulasi persepsi karyawan atas pertanyaan terbuka ketiga dapat dilihat pada Tabel 3,

Tabel 3. Rekapitulasi Hasil Pertanyaan Terbuka No. 3

\begin{tabular}{|c|c|}
\hline $\begin{array}{c}\text { Tahapan } \\
\text { Proses MK }\end{array}$ & $\begin{array}{l}\text { Pertanyaan: } \\
\text { Apa usulan Bapak/Ibu untuk perbaikan sistem penilaian kinerja di perusahaan? }\end{array}$ \\
\hline Perencanaan & $\begin{array}{l}\text { Sebanyak } 2 \% \text { responden merasa perusahaan harus memperbaiki keseluruhan sistem } \\
\text { manajemen karena sistem yang ada belum memiliki arah yang jelas } \\
\text { Sebanyak } 2 \% \text { responden merasa perusahaan harus memiliki visi dan misi yang jelas dan } \\
\text { terkomunikasikan dengan baik kepada seluruh karyawan } \\
\text { Sebanyak } 9 \% \text { responden merasa perusahaan perlu memperjelas indikator KPI yang dinilai } \\
\text { dan disesuaikan dengan uraian tugas karyawan } \\
\text { Sebanyak } 11 \% \text { responden merasa metode perencanaan yang digunakan tidak hanya searah } \\
\text { dari atasan langsung tapi juga melibatkan karyawan sendiri serta bagian/fungsi lain yang } \\
\text { banyak terlibat langsung dengan karyawan }\end{array}$ \\
\hline Pelaksanaan & $\begin{array}{l}\text { Sebanyak } 8 \% \text { responden merasa atasan perlu melakukan monitoring atas kinerja karyawan } \\
\text { baik mingguan, bulanan atau tahunan. } \\
\text { Sebanyak } 6 \% \text { responden merasa atasan perlu lebih sering mendengarkan dan melakukan } \\
\text { komunikasi dengan karyawan. } \\
\text { Sebanyak } 6 \% \text { responden merasa karyawan perlu diberikan arahan untuk perbaikan apabila } \\
\text { terdapat hal-hal tidak sesuai dengan ekspektasi perusahaan. }\end{array}$ \\
\hline
\end{tabular}




\begin{tabular}{|c|c|}
\hline $\begin{array}{l}\text { Tahapan } \\
\text { Proses MK }\end{array}$ & $\begin{array}{l}\text { Pertanyaan: } \\
\text { Apa usulan Bapak/Ibu untuk perbaikan sistem penilaian kinerja di perusahaan? }\end{array}$ \\
\hline Penilaian & $\begin{array}{l}\text { Sebanyak } 11 \% \text { responden merasa perusahaan perlu membangun SOP yang jelas, terukur } \\
\text { dan sesuai dengan kebutuhan perusahaan. } \\
\text { Sebanyak } 6 \% \text { responden merasa form penilaian kinerja yang ada harus sesuai dengan } \\
\text { kebutuhan perusahaan. } \\
\text { Sebanyak } 2 \% \text { responden merasa penilaian kinerja dilakukan secara berkala. } \\
\text { Sebanyak } 9 \% \text { responden merasa perusahaan perlu melakukan digitalisasi sistem } \\
\text { manajemen kinerja sehingga mempermudah karyawan untuk mengisi hasil yang dicapai } \\
\text { serta memudahkan atasan sebagai penilai. } \\
\text { Sebanyak } 9 \% \text { responden merasa penilaian kinerja harus dilakukan secara transparan dan } \\
\text { adil, oleh karena itu karyawan perlu dilibatkan dalam proses penilaian kinerja. } \\
\text { Sebanyak } 6 \% \text { responden merasa hasil penilaian kinerja dapat dijadikan sebagai } \\
\text { pertimbangan promosi karir yang jelas dalam perusahaan. }\end{array}$ \\
\hline $\begin{array}{l}\text { Tindak } \\
\text { Lanjut }\end{array}$ & $\begin{array}{l}\text { Sebanyak } 6 \% \text { responden merasa hasil penilaian kinerja diselaraskan dengan pemberian } \\
\text { kompensasi bagi karyawan. } \\
\text { Sebanyak } 9 \% \text { responden merasa hasil penilaian kinerja dapat dijadikan bahan pertimbangan } \\
\text { dalam menentukan pengembangan yang tepat untuk karyawan. } \\
\text { Sebanyak } 6 \% \text { responden merasa hasil penilaian kinerja dapat dijadikan sebagai } \\
\text { pertimbangan promosi karir yang jelas dalam perusahaan. }\end{array}$ \\
\hline
\end{tabular}

Sumber: Hasil Pengolahan Kuesioner Penelitian PT. AAA, 2018

\section{Hasil Studi Dokumen}

Peneliti melakukan analisa studi dokumen manajemen kinerja yang ada di perusahaan. Ada dua dokumen yang digunakan yaitu form penilaian kinerja dan SOP penilaian kinerja. Analisa ini akan disesuaikan dengan empat tahapan manajemen kinerja. Berikut adalah hasil analisa dari studi dokumen yang dapat dilihat pada Tabel 4.

Tabel 4. Hasil Identifikasi Studi Dokumen Manajemen Kinerja

\begin{tabular}{|c|c|}
\hline $\begin{array}{c}\text { Tahapan } \\
\text { Proses MK }\end{array}$ & Hasil Temuan Studi Dokumen \\
\hline \multirow[t]{5}{*}{$\begin{array}{l}\text { Perencanaan } \\
\text { Kinerja }\end{array}$} & $\begin{array}{l}\text { Diketahui bahwa perusahaan telah menurunkan indikator dari sasaran kinerja secara garis } \\
\text { besar. }\end{array}$ \\
\hline & $\begin{array}{l}\text { Tidak ditemukan adanya dokumen perjanjian kinerja yang membahas mengenai apa, } \\
\text { bagaimana dan rencana pengembangan kedepannya }\end{array}$ \\
\hline & $\begin{array}{l}\text { Jika dilihat dari form penilaian kinerja, diketahui indikator yang ada tidak disusun dengan } \\
\text { metode SMART. }\end{array}$ \\
\hline & $\begin{array}{l}\text { Jika dilihat dari form penilaian kinerja, penilaian kinerja belum mengacu pada kompetensi } \\
\text { dan belum ditemukan indikator perilaku dan tolak ukur keberhasilan dalam pekerjaan. }\end{array}$ \\
\hline & Tidak ditemukan adanya formulir perencanaan kinerja (contract agreement). \\
\hline Pelaksanaan & Tidak ditemukan adanya formulir monitoring pelaksanaan kinerja yang terstandarisasi. \\
\hline \multirow{2}{*}{ Kinerja } & Tidak ditemukan adanya dokumen mengenai pemberian umpan balik dan mentoring. \\
\hline & $\begin{array}{l}\text { Tidak ditemukan informasi yang berkaitan dengan dokumentasi data kinerja karyawan yang } \\
\text { bersangkutan. }\end{array}$ \\
\hline Penilaian & Form penilaian kinerja saat ini tidak melibatkan karyawan yang bersangkutan. \\
\hline \multirow[t]{2}{*}{ Kinerja } & $\begin{array}{l}\text { Perusahaan sudah memiliki SOP dan form penilaian yang digunakan dalam proses penilaian } \\
\text { kinerja karyawan. }\end{array}$ \\
\hline & $\begin{array}{l}\text { Form penilaian kinerja saat ini belum memenuhi ketentuan ideal dari komponen dan } \\
\text { karakteristik ideal dari sebuah form penilaian kinerja }\end{array}$ \\
\hline \multirow{3}{*}{$\begin{array}{l}\text { Tindak } \\
\text { Lanjut }\end{array}$} & Tidak ditemukan dokumen yang membahas mengenai pertemuan formal yang membahas \\
\hline & hasil penilaian kinerja karyawan \\
\hline & $\begin{array}{l}\text { Berdasarkan SOP, hasil penilaian kinerja saat ini digunakan sebagai perpanjangan kontrak, } \\
\text { kebutuhan pelatihan, dokumentasi dan keperluan administrasi lainnya }\end{array}$ \\
\hline
\end{tabular}


Berdasarkan hasil identifikasi dari hasil wawancara, FGD, suvei dan studi dokumen maka selanjutnya data tersebut akan direkapitulasi dan dibandingkan dengan kondisi ideal berdasarkan teori manajemen kinerja. Berikut adalah hasil analisis penerapan manajemen kinerja PT AAA.

Tabel 5. Hasil Analisis Penerapan Sistem Manajemen Kinerja PT AAA

\begin{tabular}{ll}
\hline $\begin{array}{c}\text { Tahapan } \\
\text { Proses MK }\end{array}$ & \multicolumn{1}{c}{$\begin{array}{c}\text { Kondisi Ideal } \\
\text { Berdasarkan Teori } \\
\text { MK }\end{array}$} \\
\hline Perencanaan & $\begin{array}{l}\text { Perusahaan perlu } \\
\text { Kenurunkan strategi } \\
\text { bisnis menjadi sasaran } \\
\text { divisi dan sasaran } \\
\text { individu agar selaras }\end{array}$ \\
& \\
& $\begin{array}{l}\text { Dalam melakukan } \\
\text { penetapan kinerja harus } \\
\text { ada panduan yang jelas } \\
\text { mengenai apa yang } \\
\text { diharapkan, bagaimana } \\
\text { proses dan rencana } \\
\text { pengembangan } \\
\text { kedepannya }\end{array}$ \\
\end{tabular}

Rekapitulasi Temuan

Berdasarkan Wawancara,

FGD, Survei dan Studi Dokumen

Perusahaan sudah menurunkan sasaran kinerja berdasarkan strategi bisnis secara umum dan belum terintegrasi secara penuh

Tidak ditemukan adanya penetapan kinerja bersama antara karyawan dan atasan yang membahas kinerja yang diharapkan, proses dan rencana pengembangan kedepannya. Sistem yang ada belum spesifik, konsisten, bebas dari kesalahan, relevan, lengkap dan detail

Penentuan target kerja dari aspek hasil dapat disusun berdasarkan uraian pekerjaan dengan metode SMART. Penentuan target dari aspek perilaku dapat disusun berdasarkan kompetensi yang dibutuhkan dan yang perlu dikembangkan dalam pekerjaan

Karyawan dilibatkan dalam melakukan perencanaan kinerja, kemudian disepakati bersama dalam contract agreement

Penentuan target kinerja dari aspek hasil masih belum memiliki tolak ukur yang jelas dan belum menggunakan metode SMART

Tidak ada penilaian kinerja yang didasari pada kompetensi yang dibutuhkan dalam ruang lingkup kerja tersebut. Sejauh ini perusahaan baru menerapkan indikator teamwork dan inisiatif saja dalam mengukur perilaku karyawan.

Perusahaan belum melibatkan karyawan yang bersangkutan dalam perencanaan target kinerja yang diharapkan dan belum memiliki contract agreement manajemen kinerja.

Diketahui divisi CL sudah menerapkan logbook mingguan yang digunakan sebagai rekap kinerja mingguan dan bulanan, hanya saja hal ini belum berlaku di seluruh divisi karena masih menjadi salah satu inisiatif divisi saja
Analisis Penerapan Manajemen Kinerja PT AAA

Pada penyusunan target kinerja, perusahaan telah menurunkan strategi bisnis menjadi indikator perencanaan hanya saja indikator ini masih umum dan belum terintegrasi secara penuh

Pada penyusunan target kinerja, tidak ditemukan adanya dokumen perencanaan dan pertemuan formal yang mendiskusikan indikator hasil, perilaku dan rencana pengembangan karyawan tersebut.

Pada penyusunan target kinerja berbasis hasil, perusahaan belum menerapkan metode SMART dalam penyusunan indikator.

Pada penyusunan target kinerja berbasis perilaku, perusahaan masih menerapkan indikator teamwork dan inisiatif saja, belum memasukkan kompetensi yang diperlukan secara keseluruhan

Pada penyusunan target kinerja, perusahaan belum melibatkan karyawan yang bersangkutan dalam melakukan perencanaan kinerja dan tidak ditemukan adanya contract agreement kinerja karyawan.

Pada pelaksanaan kinerja, belum ditemukan adanya partisipasi aktif dalam melakukan monitoring di seluruh divisi, sehingga saat ini pemberian umpan balik tergantung pada pimpinan divisi masing-masing 


\begin{tabular}{|c|c|c|c|}
\hline $\begin{array}{l}\text { Tahapan } \\
\text { Proses MK }\end{array}$ & $\begin{array}{c}\text { Kondisi Ideal } \\
\text { Berdasarkan Teori } \\
\text { MK }\end{array}$ & $\begin{array}{c}\text { Rekapitulasi Temuan } \\
\text { Berdasarkan Wawancara, } \\
\text { FGD, Survei dan Studi } \\
\text { Dokumen } \\
\end{array}$ & $\begin{array}{c}\text { Analisis Penerapan } \\
\text { Manajemen Kinerja PT AAA }\end{array}$ \\
\hline & $\begin{array}{l}\text { Atasan perlu } \\
\text { memberikan umpan } \\
\text { balik secara } \\
\text { berkelanjutan }\end{array}$ & $\begin{array}{l}\text { Pemberian umpan balik yang } \\
\text { ada masih bersifat informal dan } \\
\text { tergantung pada atasannya } \\
\text { masing-masing }\end{array}$ & $\begin{array}{l}\text { Pada pelaksanaan kinerja, } \\
\text { pemberian umpan balik yang } \\
\text { ada masih dilakukan secara } \\
\text { informal dan saat diperlukan } \\
\text { saja }\end{array}$ \\
\hline & $\begin{array}{l}\text { Atasan perlu melakukan } \\
\text { pemantauan dan } \\
\text { dokumentasi kinerja } \\
\text { karyawan }\end{array}$ & $\begin{array}{l}\text { Ada beberapa atasan yang rajin } \\
\text { melakukan pemantauan kinerja, } \\
\text { namun adapula tidak sering } \\
\text { melakukannya. }\end{array}$ & $\begin{array}{l}\text { Perusahaan belum memiliki } \\
\text { sistem pemantauan dan } \\
\text { dokumentasi kinerja karyawan } \\
\text { yang terorganisir }\end{array}$ \\
\hline & $\begin{array}{l}\text { Atasan perlu } \\
\text { memberikan dorongan, } \\
\text { membantu dan } \\
\text { mengembangkan } \\
\text { karyawan dalam proses } \\
\text { pelaksanaan kinerja }\end{array}$ & $\begin{array}{l}\text { Tidak ada pertemuan formal } \\
\text { dimana atasan dapat } \\
\text { memberikan dorongan dan } \\
\text { membantu karyawan dalam } \\
\text { proses pelaksanaan kerja }\end{array}$ & $\begin{array}{l}\text { Perusahaan belum mengadakan } \\
\text { pertemuan formal berkala } \\
\text { dimana atasan dapat } \\
\text { memberikan dorongan dan } \\
\text { membantu karyawan dalam } \\
\text { proses pelaksanaan kerja }\end{array}$ \\
\hline & $\begin{array}{l}\text { Karyawan perlu } \\
\text { mengkomunikasikan } \\
\text { hal-hal yang berkaitan } \\
\text { dengan pekerjaan } \\
\text { dengan atasan mereka }\end{array}$ & $\begin{array}{l}\text { Belum ditemukan adanya } \\
\text { pertemuan mingguan atau } \\
\text { bulanan bagi karyawan untuk } \\
\text { mengkomunikasikan } \\
\text { permasalahan yang dapat } \\
\text { mempengaruhi pekerjaan } \\
\text { mereka secara terbuka }\end{array}$ & $\begin{array}{l}\text { Perusahaan belum } \\
\text { memfasilitasi karyawan untuk } \\
\text { mengkomunikasikan } \\
\text { permasalahan mereka secara } \\
\text { terbuka }\end{array}$ \\
\hline & $\begin{array}{l}\text { Karyawan perlu } \\
\text { melakukan umpan balik } \\
\text { dan coaching secara } \\
\text { berkelanjutan dari atasan }\end{array}$ & $\begin{array}{l}\text { Belum ditemukan adanya } \\
\text { sistem coaching dan mentoring } \\
\text { secara berkelanjutan }\end{array}$ & $\begin{array}{l}\text { Perusahaan belum menyusun } \\
\text { sistem dimana karyawan dan } \\
\text { atasan dapat melakukan sesi } \\
\text { umpan balik dan coaching } \\
\text { secara berkelanjutan }\end{array}$ \\
\hline & $\begin{array}{l}\text { Karyawan } \\
\text { mengumpulkan data } \\
\text { kinerja dan } \\
\text { mempersiapkan } \\
\text { penilaian kinerja }\end{array}$ & $\begin{array}{l}\text { Perusahaan belum membuat } \\
\text { sebuah sistem informasi yang } \\
\text { berkaitan dengan dokumentasi } \\
\text { data kinerja karyawan yang } \\
\text { bersangkutan. }\end{array}$ & $\begin{array}{l}\text { Perusahaan belum membuat } \\
\text { sebuah sistem informasi dimana } \\
\text { karyawan dapat } \\
\text { mendokumentasikan data } \\
\text { kinerja untuk menjadi } \\
\text { pertimbangan penilaian }\end{array}$ \\
\hline & $\begin{array}{l}\text { Seluruh stakeholder } \\
\text { harus berperan aktif } \\
\text { dalam melakukan } \\
\text { evaluasi dengan } \\
\text { mempertahankan } \\
\text { komunikasi dua arah }\end{array}$ & $\begin{array}{l}\text { Perusahaan belum menerapkan } \\
\text { sistem dua arah dalam penilaian } \\
\text { kinerja. SOP dan form } \\
\text { penilaian kinerja tahunan juga } \\
\text { tidak diinformasikan pada } \\
\text { karyawan yang bersangkutan. }\end{array}$ & $\begin{array}{l}\text { Seluruh stakeholder belum } \\
\text { berperan aktif dan informasi } \\
\text { yang berkaitan dengan } \\
\text { penilaian kinerja belum bersifat } \\
\text { dua arah }\end{array}$ \\
\hline
\end{tabular}

Sumber: PT. AAA, 2018

Tabel 5. Hasil Analisis Penerapan Sistem Manajemen Kinerja PT AAA 


\begin{tabular}{|c|c|c|c|}
\hline $\begin{array}{c}\text { Tahapan Proses } \\
\text { MK }\end{array}$ & $\begin{array}{c}\text { Kondisi Ideal } \\
\text { Berdasarkan Teori } \\
\text { MK }\end{array}$ & $\begin{array}{c}\text { Rekapitulasi Temuan } \\
\text { Berdasarkan Wawancara, } \\
\text { FGD, Survei dan Studi } \\
\text { Dokumen }\end{array}$ & $\begin{array}{c}\text { Analisis Penerapan } \\
\text { Manajemen Kinerja PT } \\
\text { AAA }\end{array}$ \\
\hline \multirow[t]{4}{*}{ Penilaian Kinerja } & $\begin{array}{l}\text { Karyawan dapat } \\
\text { menilai dirinya sendiri } \\
\text { sebelum diberikan ke } \\
\text { atasan. }\end{array}$ & $\begin{array}{l}\text { Karyawan tidak melakukan } \\
\text { self-assesment, hanya atasan } \\
\text { yang bisa melakukan } \\
\text { penilaian kinerja dan hasilnya } \\
\text { akan langsung diserahkan } \\
\text { kepada SDM. }\end{array}$ & $\begin{array}{l}\text { Pada tahap penilaian kinerja, } \\
\text { karyawan tidak menilai } \\
\text { kinerja mereka. }\end{array}$ \\
\hline & $\begin{array}{l}\text { Penilaian yang } \\
\text { dilakukan mengacu } \\
\text { pada penetapan kinerja } \\
\text { yang telah disepakati }\end{array}$ & $\begin{array}{l}\text { Banyak karyawan yang tidak } \\
\text { mengerti prosedur dan sistem } \\
\text { manajemen kinerja yang ada } \\
\text { di perusahaan karena tidak } \\
\text { ada kesepakatan sebelumnya } \\
\text { sehingga tidak diketahui mana } \\
\text { pekerjaan yang efektif dan } \\
\text { tidak efektif. }\end{array}$ & $\begin{array}{l}\text { Perusahaan tidak melakukan } \\
\text { penetapan kinerja, sehingga } \\
\text { banyak karyawan yang } \\
\text { merasa tidak adil dengan hasil } \\
\text { yang mereka terima, bahkan } \\
\text { beberapa diantara karyawan } \\
\text { tidak mengetahui adanya } \\
\text { sistem penilaian kinerja di } \\
\text { perusahaan }\end{array}$ \\
\hline & $\begin{array}{l}\text { Diperlukan prosedur } \\
\text { dan form penilaian } \\
\text { yang jelas dalam sitem } \\
\text { penilaian kinerja }\end{array}$ & $\begin{array}{l}\text { Pada tahap penilaian kinerja, } \\
\text { perusahaan telah menyusun } \\
\text { SOP dan form penilaian } \\
\text { kinerja, hanya saja SOP yang } \\
\text { ada hanya terbatas pada } \\
\text { penilaian saja belum } \\
\text { mencakup keseluruhan sistem } \\
\text { manajemen kinerja dan form } \\
\text { penilaian kinerja belum } \\
\text { memenuhi ketentuan ideal } \\
\text { sehingga banyak karyawan } \\
\text { yang merasa kurang adil } \\
\text { Perusahaan dapat melakukan } \\
\text { digitalisasi atas prosedur } \\
\text { penilaian sehingga akan lebih } \\
\text { memudahkan proses penilaian } \\
\text { kinerja. }\end{array}$ & $\begin{array}{l}\text { Pada tahap penilaian kinerja, } \\
\text { perusahaan belum memiliki } \\
\text { prosedur yang mencakup } \\
\text { seluruh tahapan dalam proses } \\
\text { manajemen kinerja dan form } \\
\text { penilaian yang ada masih } \\
\text { belum memenuhi kondisi } \\
\text { ideal. Perusahaan juga perlu } \\
\text { melakukan digitalisasi pada } \\
\text { sistem penilaian kinerja } \\
\text { karyawan. }\end{array}$ \\
\hline & $\begin{array}{l}\text { Atasan harus menilai } \\
\text { dengan objektif dan } \\
\text { meminimalisir error }\end{array}$ & $\begin{array}{l}\text { Pada tahap penilaian kinerja, } \\
\text { karyawan tidak memiliki sesi } \\
\text { formal dan tidak bisa } \\
\text { mengajukan banding atas } \\
\text { hasil penilaian kinerja yang } \\
\text { mereka dapatkan }\end{array}$ & $\begin{array}{l}\text { Atasan tidak mengadakan sesi } \\
\text { formal dan karyawan tidak } \\
\text { bisa mengajukan banding } \\
\text { sehingga penilaian belum } \\
\text { bersifat objektif dan error } \\
\text { dapat diminimalisir. }\end{array}$ \\
\hline \multirow[t]{2}{*}{ Tindak Lanjut } & $\begin{array}{l}\text { Perlu diadakan sesi } \\
\text { formal untuk } \\
\text { membahas hasil } \\
\text { kinerja dan tindak } \\
\text { lanjut atas hasil } \\
\text { penilaian kinerja. }\end{array}$ & $\begin{array}{l}\text { Pada tahap tindak lanjut, } \\
\text { perusahaan belum } \\
\text { mengadakan sesi formal yang } \\
\text { membahas mengenai hasil } \\
\text { penilaian kinerja yang mereka } \\
\text { dapatkan }\end{array}$ & $\begin{array}{l}\text { Pada tahap tindak lanjut, } \\
\text { perusahaan belum } \\
\text { mengadakan sesi formal yang } \\
\text { membahas mengenai hasil } \\
\text { penilaian kinerja yang mereka } \\
\text { dapatkan }\end{array}$ \\
\hline & $\begin{array}{l}\text { Hasil penilaian kinerja } \\
\text { dapat menjadi acuan } \\
\text { dalam pemberian } \\
\text { reward berbentuk } \\
\text { finansial ataupun non } \\
\text { finansial }\end{array}$ & $\begin{array}{l}\text { Pada tahap tindak lanjut, hasil } \\
\text { penilaian kinerja yang ada } \\
\text { masih digunakan untuk } \\
\text { pemberian reward yang } \\
\text { bersifat non finansial. } \\
\text { Diharapkan hasil penilaian }\end{array}$ & $\begin{array}{l}\text { Hasil penilaian kinerja yang } \\
\text { ada masih digunakan untuk } \\
\text { pemberian reward yang } \\
\text { bersifat non finansial, } \\
\text { perusahaan perlu } \\
\text { mempertimbangkan reward }\end{array}$ \\
\hline
\end{tabular}




\begin{tabular}{cccc}
\hline $\begin{array}{c}\text { Tahapan Proses } \\
\text { MK }\end{array}$ & $\begin{array}{c}\text { Kondisi Ideal } \\
\text { Berdasarkan Teori } \\
\text { MK }\end{array}$ & $\begin{array}{c}\text { Rekapitulasi Temuan } \\
\text { Berdasarkan Wawancara, } \\
\text { FGD, Survei dan Studi } \\
\text { Dokumen }\end{array}$ & $\begin{array}{c}\text { Analisis Penerapan } \\
\text { Manajemen Kinerja PT } \\
\text { AAA }\end{array}$ \\
\hline & $\begin{array}{l}\text { kinerja kedepannya dapat } \\
\text { digunakan sebagai alat } \\
\text { kontrol dan terintegrasi } \\
\text { dengan kegiatan SDM lainnya }\end{array}$ & $\begin{array}{l}\text { yang bersifat finansial dan } \\
\text { hasil penilaian dapat dijadikan } \\
\text { alat kontrol dan terintegrasi } \\
\text { dengan kegiatan SDM } \\
\text { lainnya. }\end{array}$ \\
\hline
\end{tabular}

Sumber: PT. AAA, 2018

\section{Implikasi Manajerial}

Berdasarkan hasil analisis penerapan manajemen kinerja yang ada di perusahaan, secara umum diketahui pada tahap perencanaan kinerja diketahui perusahan belum menurunkan sasaran secara strategis dan belum melakukan penetapan sasaran kinerja secara dua arah. Pada tahap pelaksanaan kinerja ditemukan bahwa perusahaan belum mengadakan pertemuan kinerja secara formal dan terjadwal. Pada tahap penilaian kinerja, diketahui bahwa karyawan tidak dilibatkan dalam penilaian dan pada tahap tindak lanjut diketahui hasil kinerja belum dimanfaatkan secara efektif. Oleh karena itu diperlukan arahan perbaikan dalam implikasi manajerial untuk sistem manajemen kinerja perusahaan kedepannya.

Adapun arahan perbaikan yang bisa dilakukan untuk manajemen kinerja berikutnya adalah sebagai berikut:

\section{Perencanaan Kinerja}

Arahan perbaikan manajemen kinerja pada tahap perencanaan kinerja adalah sebagai berikut:

a. Menyusun sasaran kinerja yang diturunkan dari strategi bisnis dan target divisi. Sasaran kinerja juga selaras dengan uraian tugas karyawan.

b. Sasaran kinerja yang disusun terdiri dari aspek hasil dan proses. Sasaran aspek hasil disusun dengan metode SMART sehingga tolak ukur menjadi jelas. Sasaran aspek proses disusun dengan mempertimbangkan kompetensi yang dibutuhkan dalam lingkup pekerjaan karyawan.

c. Perusahaan perlu menyusun contract agreement kinerja yang mencakup target kinerja dan rencana pengembangan karyawan dalam kurun waktu satu tahun. Proses penyusunan ini harus dilakukan dengan komunikasi dua arah sehingga perusahaan perlu mengadakan performance plan meeting dengan karyawan yang bersangkutan.

d. Menyusun sebuah pedoman manajemen kinerja yang berisi informasi mengenai sistem manajemen kinerja, panduan yang jelas atas apa yang diharapkan, bagaimana proses dan rencana pengembangan kedepannya. Perusahaan perlu menyusun SOP yang jelas dalam proses penerapan manajemen kinerja secara keseluruhan sistem di perusahaan.

2. Pelaksanaan Kinerja

Arahan perbaikan manajemen kinerja pada tahap perencanaan kinerja adalah sebagai berikut: 
a. Karyawan dan atasan perlu membuat form catatan kerja karyawan yang terdiri dari rincian aktivitas, durasi pekerjaan, permasalahan yang dihadapi, target penyelesaian dan catatan dari atasan.

b. Setiap divisi wajib mengadakan meeting mingguan yang membahas target kinerja, progres dan permasalahan yang dihadapi secara tim.

c. Pemimpin tim dan pemimpin divisi perlu menyusun jadwal pertemuan formal dan informal yang membahas tentang hal-hal yang berhubungan dengan performa karyawan. Umpan balik, coaching, counselling dan mentoring akan dilakukan pada sesi ini. Perusahaan juga perlu menerapkan sistem informasi untuk dokumentasi kinerja

3. Penilaian Kinerja

Arahan perbaikan manajemen kinerja pada tahap perencanaan kinerja adalah sebagai berikut:

a. Proses penilaian manajemen kinerja harus sesuai dengan kesepakatan pada tahap perencanaan kinerja dengan orientasi proses dan hasil. Proses penilaian kinerja perlu di sosialisasikan secara menyeluruh sehingga setiap karyawan memahami prosedur dan SOP manajemen kinerja yang berlaku.

b. Penilaian kinerja harus melibatkan karyawan yang bersangkutan dan atasan. Karyawan perlu melakukan self-appraisal terlebih dahulu atas kinerja di form penilaian setelah itu atasan memberikan penilaian di form penilaian yang sama. Setelah dilakukan penilaian kinerja secara mandiri, atasan dan bawahan harus mendiskusikan hasil tersebut sehingga mengurangi subjektivitas penilaian.

c. Sistem penilaian kinerja sebaiknya didigitalisasi sehingga akan lebih mudah bagi karyawan dalam melakukan penilaian dan perusahaan dalam proses dokumentasi hasil kinerja karyawannya.

4. Tindak Lanjut Kinerja

Arahan rancangan manajemen kinerja pada tahap perencanaan kinerja adalah sebagai berikut:

a. Mengadakan sesi formal yang membahas hasil penilaian kinerja, melakukan perbandingan hasil kinerja tahun ini dan tahun sebelumnya sehingga hasil penilaian dapat dijadikan alat kontrol, dokumentasi, evaluasi dan penetapan kebijakan selanjutnya.

b. Memastikan rancangan manajemen kinerja dapat menjadi pertimbangan dalam pemberian reward finansial dan non finansial

\section{KESIMPULAN DAN SARAN}

Berdasarkan hasil analisa penerapan manajemen kinerja di PT AAA yang telah dilakukan sebelumnya, diketahui bahwa terdapat beberapa permasalahan yang ada di perusahaan. Permasalahan dibagi menjadi beberapa tahapan. Pada tahap perencanaan kinerja diketahui perusahaan kurang memberikan sosialisasi mengenai sistem penilaian kinerja, penetapan target kinerja belum disesuaikan 
dengan sasaran bisnis perusahaan, indikator belum SMART dan belum selaras dengan uraian pekerjaan. Pada tahap pelaksanaan kinerja, perusahaan belum melakukan standarisasi pertemuan formal dan informal terkait kinerja karyawan dan belum ada proses dokumentasi kinerja, pada tahap penilaian kinerja perusahaan belum melakukan komunikasi secara dua arah sehingga karyawan tidak mengetahui adanya proses penilaian kinerja. Pada tahap tindak lanjut, sejauh ini hasil penilaian hanya digunakan untuk penghargaan non-finansial saja. Perusahaan juga mengharapkan sistem manajemen kinerja dapat digitalisasi sehingga akan memudahkan karyawan dalam proses penilaian.

Berdasarkan hasil tersebut, maka diperlukan arahan perbaikan pada masing-masing tahapan yang manajemen kinerja mulai dari perencanaan, pelaksanaan, penilaian dan tindak lanjut kinerja sesuai dengan arahan yang telah dijelaskan pada bagian sebelumnya. Penting bagi perusahaan untuk konsisten dan memperbaiki sistem manajemen yang ada sekarang sesuai dengan arahan yang ada. Adapun saran lanjutan terkait penelitian ini adalah membuat rancangan sistem manajemen kinerja sesuai arahan perbaikan manajemen kinerja di PT AAA. 


\section{DAFTAR PUSTAKA}

Aguinis, H.(2014). Performance Management, USA: Pearson

Armstrong, M. (2006). Performance Management:Key Strategies and Practical Guidelines, UK: Thomson -Shore Inc

Hague. (1995). Merancang Kuesioner, Jakarta: Pustaka Binaman Pressindo

Ken Research. (2019). Indonesia Logistics and Warehousing Market Future, March 2019.

Laksono. (2012). The Role of 4PL as Supply Chain Integrator, Seminar Nasional dan Akutansi Bisnis, $1446-1454$

Prospeknya Cerah, Bisnis Logistik Diprediksi Tumbuh Lebih dari 30\% di 2020. (2019), diakses 15 Januari dari https://katadata.co.id/

Rencana Jangka Panjang PT AAA Indonesia 2019-2024. (2019). PT PT AAA Indonesia

Sekaran, Uma. (2011). Metode Penelitian Bisnis, Jakarta: Salemba Empat

Spencer, P. M., \& S. M. Spencer. (1993). Competence at Work: Models for Superior Performance. New York: John Wiley \& Sons, Inc.

Weiss, Tracey B.dan Hartle, Franklin. (1997). Reengineering Performance Management, New York: St. Lucie Press. 


\section{LAMPIRAN}

Lampiran 1 Hasil Wawancara Penerapan Manajemen Kinerja PT AAA

\begin{tabular}{|c|c|}
\hline $\begin{array}{c}\text { Tahapan } \\
\text { Proses MK }\end{array}$ & VP SDM \\
\hline \multirow[t]{2}{*}{ Perencanaan } & $\begin{array}{l}\text { Kita sudah mulai dari } \\
\text { 2017, cuma masih } \\
\text { proses, masih trial dan } \\
\text { learn }\end{array}$ \\
\hline & $\begin{array}{l}\text { Kita sudah coba } \\
\text { cascade, cuma } \\
\text { memang ditekankan } \\
\text { dari sisi keuangannya } \\
\text { karena itu yang paling } \\
\text { terlihat. Biasanya } \\
\text { menjadi tolak ukur ya } \\
\text { keuangan trus absensi. } \\
\text { Intinya kita lihat } \\
\text { gimana hasil sama } \\
\text { perilaku dia di kantor }\end{array}$ \\
\hline
\end{tabular}

Inisiatif dari VP untuk

Sekarang sistemnya masih top-down, bukan dari bawah, tapi kalau dalam memperkirakan target, biasanya dilibatkan. mencascade hingga ke individu di $\mathrm{HO}$, brand Jakarta dan untuk per individunya juga. Tapi untuk komunikasi secara langsung ke karyawan yang bersangkutan belum ada, belum ditegaskan.

Hmm.. ya sudah sih ya mba kalo garis besarnya, cuma memang belum sama persis, semoga kedepannya bisa selaras penuh

Pelaksanaan Kalau sesi formal belum ada,

Kalau itu ada mbak, malah biasanya kita tetap

Wawancar
VP FF

OFF-SDM

\section{Kesimpulan}

Perusahaan sudah

menerapkan

manajemen kinerja

sejak tahun lalu, hanya

saja sistem yang ada

masih perlu diperbaiki

Penilaian kinerja yang ada sudah diturunkan dari strategi bisnis yang

ada di perusahaan namun cenderung keuangan dan absensi. Sudah ada pengukuran untuk hasil dan proses namun kurang sistematis. pekerjaan dan kita kurang meeting juga. Jarang sekali ada meeting dan sosialisasi strategi bisnis perusahaan.

Seharusnya kan semuanya harus didukung dari atas tapi sebenernya kita ga tau yang didukung itu apa. Jadi kita yang dibawah jadi nebak-nebak aja.

Perencanaan kinerja yang ada masih bersifat satu arah dan belum melibatkan karyawan yang bersangkutan secara langsung

pekerjaan yang biasanya kita kerjain itu sebenernya emang diturunkan dari atasan cuman ga sistematis saya supervisi langsung kerjaan mereka.
Manajer belum pernah melakukan coaching dan monitoring terstruktur, adanya selama ini arahan secara ga langsung.
Penyusunan kerja sudah menyesuaikan uraian tugas secara garis besar, namun memang belum selaras penuh dengan uraian tugas yang ada dan karyawan merasa penurunannya tidak sistematis

Karyawan dan atasan belum berpartisipasi secara aktif karena belum ada sistem pelaksanaan kinerja yang terstruktur dan terjadwal. Pelaksanaan kinerja bergantung pada atasan masing-masing mulai dari proses umpan balik, 


\begin{tabular}{|c|c|c|c|c|}
\hline \multirow{2}{*}{$\begin{array}{c}\text { Tahapan } \\
\text { Proses MK }\end{array}$} & \multicolumn{3}{|c|}{ Wawancara } & \multirow{2}{*}{ Kesimpulan } \\
\hline & VP SDM & VP FF & OFF-SDM & \\
\hline & & & & $\begin{array}{l}\text { dokumentasi dan proses } \\
\text { monitoring lainnya. } \\
\text { Beberapa atasan } \\
\text { melakukan supervisi } \\
\text { langsung kepada } \\
\text { bawahannya. }\end{array}$ \\
\hline & & & $\begin{array}{l}\text { Kalau di divisi } \\
\text { saya, jarang sekali } \\
\text { ada meeting yang } \\
\text { ngomongin target } \\
\text { mingguan atau } \\
\text { bulanan, taunya } \\
\text { cuma kerja aja, } \\
\text { ngikutin apa yang } \\
\text { disuruh sama } \\
\text { atasan. }\end{array}$ & $\begin{array}{l}\text { Beberapa divisi tidak } \\
\text { memiliki meeting } \\
\text { mingguan dan bulanan. }\end{array}$ \\
\hline \multirow[t]{3}{*}{$\begin{array}{l}\text { Penilaian } \\
\text { Kinerja }\end{array}$} & $\begin{array}{l}\text { Kita merencanakan } \\
\text { akan dilakukan tiap } 3 \\
\text { bulan, tapi saat ini } \\
\text { bersifat akhir tahun. }\end{array}$ & & & $\begin{array}{l}\text { Penilaian kinerja } \\
\text { dilakukan pada akhir } \\
\text { tahun }\end{array}$ \\
\hline & $\begin{array}{l}\text { Penilaian kinerja } \\
\text { karyawan di lakukan } \\
\text { oleh VPHC, dan itu } \\
\text { disesuaikan oleh data } \\
\text { yang ada, oleh karena } \\
\text { itu kebanyakan dari } \\
\text { keuangan, kalau di BO } \\
\text { penilaian ada di BM, } \\
\text { tapi sebenernya data } \\
\text { yang ada itu dari } \\
\text { aktivitas sehari-hari. } \\
\text { Setiap aktivitas sehari- } \\
\text { hari ada recordnya, } \\
\text { itulah yang naik } \\
\text { keatas. }\end{array}$ & $\begin{array}{l}\text { Pernah sih pernah } \\
\text { mbak, cuma } \\
\text { sebenernya saya } \\
\text { juga bingung dalam } \\
\text { menilai, soalnya } \\
\text { banyak staff saya } \\
\text { yang kerjaannya } \\
\text { double double, } \\
\text { kadang ngurusin } \\
\text { FF, CL sama yang } \\
\text { lain-lain, jadi } \\
\text { sebenernya saya } \\
\text { bingung nilainya, } \\
\text { karena banyak ga } \\
\text { fokus kerjanya. }\end{array}$ & $\begin{array}{l}\text { Saya tidak tahu } \\
\text { kalau ada penilaian } \\
\text { kinerja secara } \\
\text { terstruktur, selama } \\
\text { saya disini (3 } \\
\text { tahun), baru ada } \\
\text { sekali penilaian } \\
\text { kinerja, itu juga } \\
\text { karena kontraknya } \\
\text { sudah mau habis, } \\
\text { nah itu juga saya } \\
\text { bingung gimana } \\
\text { cara ngisi yang } \\
\text { sebenarnya, } \\
\text { penilaiannya sangat } \\
\text { general, seperti } \\
\text { kemampuan } \\
\text { mengerjakan. Tidak } \\
\text { ada realistis dan } \\
\text { terukur. Seingat } \\
\text { saya ya belom } \\
\text { pernah kalo sesuai } \\
\text { standarnya dari } \\
\text { awal sampai akhir, } \\
\text { makanya disini } \\
\text { biasanya kinerjanya } \\
\text { cuma dilihat dari } \\
\text { absen saja }\end{array}$ & $\begin{array}{l}\text { Penilaian kinerja } \\
\text { dilakukan oleh atasan } \\
\text { yang bersangkutan saja, } \\
\text { tanpa melibatkan } \\
\text { karyawan yang } \\
\text { bersangkutan. Beberapa } \\
\text { atasan masih bingung } \\
\text { dalam memberikan } \\
\text { penilaian kepada } \\
\text { karyawannya karena } \\
\text { belum ada standar pasti } \\
\text { dalam melakukan } \\
\text { penilaian kinerja }\end{array}$ \\
\hline & $\begin{array}{l}\text { Hmm.. saya rasa tidak } \\
\text { perlu ada banding ya, } \\
\text { kan datanya dari } \\
\text { record mereka sediri. }\end{array}$ & & & $\begin{array}{l}\text { Penilaian kinerja tidak } \\
\text { dapat dibanding. }\end{array}$ \\
\hline
\end{tabular}




\begin{tabular}{|c|c|c|c|c|}
\hline \multirow{2}{*}{$\begin{array}{c}\text { Tahapan } \\
\text { Proses MK }\end{array}$} & \multicolumn{3}{|c|}{ Wawancara } & \multirow{2}{*}{ Kesimpulan } \\
\hline & VP SDM & VP FF & OFF-SDM & \\
\hline \multirow{4}{*}{$\begin{array}{l}\text { Tindak } \\
\text { Lanjut }\end{array}$} & $\begin{array}{l}\text { Sudah ya kalau itu, } \\
\text { saya rasa bukan } \\
\text { masalah kalau norma }\end{array}$ & & & $\begin{array}{l}\text { Perusahaan melakukan } \\
\text { penilaian kinerja sesuai } \\
\text { norma dan etika yang } \\
\text { berlaku }\end{array}$ \\
\hline & $\begin{array}{l}\text { Kalau sesi formal } \\
\text { belum ada }\end{array}$ & & & $\begin{array}{l}\text { Hasil penilaian belum } \\
\text { dikomunikasikan ke } \\
\text { pihak terkait. } \\
\text { Perusahaan belum } \\
\text { mengagendakan } \\
\text { pertemuan formal } \\
\text { terkait manajemen } \\
\text { kinerja. }\end{array}$ \\
\hline & $\begin{array}{l}\text { Sekarang sih belum } \\
\text { ya, tapi kedepannya } \\
\text { inginnya seperti itu }\end{array}$ & & $\begin{array}{l}\text { Nah disini } \\
\text { rewardnya tidak } \\
\text { berbasis kinerja, } \\
\text { karena kurang } \\
\text { record kerja }\end{array}$ & $\begin{array}{l}\text { Hasil penilaian kinerja } \\
\text { tidak mempengaruhi } \\
\text { kompensasi karyawan } \\
\text { saat ini, namun } \\
\text { kedepannya diharapkan } \\
\text { hasil kinerja dapat } \\
\text { mempengaruhi } \\
\text { kompensasi }\end{array}$ \\
\hline & $\begin{array}{l}\text { Harapannya, sistem } \\
\text { KPI dapat berjalan } \\
\text { baik sesuai dengan } \\
\text { kebutuhan dan } \\
\text { menjadi tools } \\
\text { perusahaan untuk } \\
\text { mengendalikan } \\
\text { karyawan dengan } \\
\text { efektif dan semakin } \\
\text { sempurna kedepannya } \\
\text { dan ada aplikasinya }\end{array}$ & $\begin{array}{l}\text { Harapan saya } \\
\text { manajemen kinerja } \\
\text { dapat menjadi } \\
\text { rumus } \\
\text { perhitungan/alat } \\
\text { yang digunakan } \\
\text { oleh perusahaan } \\
\text { sebagai bahan } \\
\text { pertimbangan yang } \\
\text { strategis dalam } \\
\text { menyusun } \\
\text { kebijakan dan } \\
\text { kegiatan } \\
\text { operasional yang } \\
\text { ada di perusahaan }\end{array}$ & . & $\begin{array}{l}\text { Manajemen kinerja } \\
\text { dapat menjadi alat } \\
\text { kontrol kinerja dan } \\
\text { pertimbangan strategis } \\
\text { kedepannya. }\end{array}$ \\
\hline
\end{tabular}


Lampiran 2 Hasil FGD Penerapan Manajemen Kinerja Divisi Contract Logistics PT AAA

\section{Tahapan}

Perencanaan

Penilaian

Tindak Lanjut

Pelaksanaan
FGD

Kesimpulan

Saat itu saya yang menilai dengan form yang dikasih dengan SDM. Objek tidak mengetahui apa yang dinilai karena memang begitu instruksinya dari SDM, jadi wajar aja mereka ga pernah liat formnya sama sekali.

Kita sih biasanya disini pakenya log book mingguan, ada rincian tugas apa yang harus saya kerjain trus nanti di cek sama atasannya, udah tercapai ga kita punya kerjaan. Itu yang buat VP saya.

Saat itu saya yang menilai dengan form yang dikasih dengan SDM. Untuk form penilaian kinerja itu saya kerjakan sendiri, ga ada saya libatkan anak buah saya dan objek tidak mengetahui apa yang dinilai karena memang begitu instruksinya dari SDM, jadi wajar aja mereka ga pernah liat formnya sama sekali.

Ya saya buat semua dan sudah saya kasih ke SDM juga

Kalau dari saya ya mba, saya ingin semua sistem itu di digitalisasi supaya jelas gimana gimananya.

Jadi akan ada form penilaian kinerjanya selama ini, gimana dia kerjanya, apakah memenuhi syarat untuk kembali dilanjutkan kontraknya. Kalau dia memenuhi berarti kontraknya diperpanjang.

Terus ya mba, kalau bisa seluruh kegiatan SDM itu dapat terintegrasi dengan baik mulai dari perencanaan hingga ke kompensasinya.
Perencanaan manajemen kinerja adalah kewenangan SDM. Sejauh ini karyawan tidak dilibatkan secara langsung dalam proses perencanaan kinerja. Tidak ada pertemuan khusus antara atasan dan bawahan dalam membahas perencanaan kinerja.

Pelaksanaan kinerja yang ada di divisi kinerja dilakukan oleh atasan dan bawahan secara dua arah. Atasan melakukan pemantauan atas pekerjaan yang dilakukan. Atasan memberi umpan balik secara berkelanjutan. Karyawan melakukan tugasnya sesuai ruang lingkup yang telah diberikan oleh atasan. Karyawan dan atasan melakukan komunikasi dua arah terkait pekerjaan yang dilakukan

Hanya atasan yang melakukan penilaian kinerja tanpa berkomunikasi dengan karyawan yang bersangkutan, dan hasilnya langsung diberikan ke pihak SDM.Penilaian kinerja saat ini hanya dilakukan oleh atasan saja dan tidak melibatkan karyawan yang bersangkutan. Beberapa Karyawan tidak mengetahui ada sistem penilaian kinerja di perusahaan.

Diharapkan perusahaan kedepannya dapat melakukan digitalisasi atas prosedur penilaian sehingga akan lebih memudahkan proses penilaian kinerja.

Hasil penilaian kinerja yang ada akan digunakan untuk perpanjangan kontrak karyawan.

Diharapkan manajemen kinerja kedepannya dapat terintegrasi dengan seluruh kegiatan SDM lainnya. 